\title{
Pumpkin response to microirrigation in two agro-ecological regions in Puerto Rico ${ }^{1,2}$
}

\author{
Elvin Román-Paoli ${ }^{3}$, Sonia Martínez-Garrastazú ${ }^{4}$, Luisa Flores ${ }^{5}$ \\ and Luis Almodóvar ${ }^{6}$
}

J. Agric. Univ. P.R. 96 (3-4):139-153 (2012)

\begin{abstract}
Pumpkin [Cucurbita moschata (Duchesne) Poir], one of the most important vegetable crops in the Caribbean, ranking second among all the vegetables produced in Puerto Rico, had a farm value of 4.1 million dollars for the 2009-2010 growing season. Drip irrigation is the method most commonly used to meet water requirements in many of the vegetables planted in Puerto Rico. However, more information is needed on water requirements and response to different applications. An experiment was established using Pan A evaporation readings to determine the appropriate microirrigation management practices to enhance pumpkin production. Pumpkin plants were treated with four microirrigation applications, consisting of four levels of evapotranspiration replenishment (ERT) treatments. The ERT levels used were $25,50,75$ and $100 \%$; levels were based on evaporation data recorded at two locations in southwestern Puerto Rico (Lajas and Juana Díaz). The Pan A evaporation method was utilized to estimate reference evapotranspiration $\left(E T_{0}\right)$ and pumpkin evapotranspiration $\left(E_{C}\right)$. The ERT did not significantly and consistently affect total leaf area, biomass or yield at both locations, although occasionally significant interactions were found between ERT and leaf areas and biomass measured through time. On the basis of a two-year average, commercial yield in Juana Díaz tended to be higher than yield in Lajas by $1,594 \mathrm{~kg} / \mathrm{ha}$. Juana Díaz showed higher water use efficiency than Lajas. The $\mathrm{ET}_{\mathrm{c}}$ estimates were found to be lower in Lajas.
\end{abstract}

Key words: pumpkin, yield, evapotranspiration, Pan Evaporation

\section{RESUMEN}

Respuesta de calabaza a microriego en dos regiones agro-ecológicas en Puerto Rico

${ }^{1}$ Manuscript submitted to Editorial Board 9 March 2012.

${ }^{2}$ We would like to thank Dr. Gumersindo Ramírez-Oliveras, our colleague and friend, for helping in the edition of this paper.

${ }^{3}$ Professor, Department of Crops and Agroenvironmental Sciences, College of Agricultural Sciences, University of Puerto Rico, Mayagüez Campus. HC-02 Box 11656, Lajas, PR 00667-9714. email: elvin.roman@upr.edu

${ }^{4}$ Associate Horticulturist, Department of Crops and Agroenvironmental Sciences.

${ }^{5}$ Research Associate, Lajas Substation, Agricultural Experiment Station.

${ }^{6}$ Research Associate, Mayagüez Research and Development Center, Agricultural Experiment Station. 
La calabaza [Cucurbita moschata (Duchesne) Poir], una de las hortalizas más importantes en el Caribe, ocupa el segundo lugar entre las hortalizas producidas en Puerto Rico y tuvo un valor a nivel de finca de 4.1 millones de dólares durante el 2009-2010. El riego por goteo (microriego) es el método más comúnmente utilizado para satisfacer los requisitos de humedad de la mayoría de las hortalizas cultivadas en Puerto Rico. Sin embargo, se requiere más información sobre los requisitos hídricos y la respuesta del cultivo a diferentes aplicaciones de los mismos. Se realizó un experimento utilizando lecturas de la bandeja de evaporación para determinar las prácticas de manejo de microriego adecuadas y para cuantificar la respuesta del cultivo de calabaza. Las plantas de calabaza se trataron con cuatro aplicaciones de microriego que consistieron de cuatro niveles de reposición de evapotranspiración (ERT). Los niveles de ERT utilizados fueron 25, 50, 75 y $100 \%$, los cuales se basaron en datos de evaporación registrados en dos localidades del suroeste de Puerto Rico (Lajas y Juana Díaz). Se utilizó el método de la bandeja o tanque de evaporación para estimar la evapotranspiración de referencia $\left(\mathrm{ET}_{0}\right)$ y la evapotranspiración del cultivo $\left(E T_{c}\right)$. En ambas localidades, la ERT no afectó significativa y consistentemente el área foliar total, ni la biomasa ni el rendimiento, aunque en ocasiones se encontraron interacciones significativas entre tratamiento y área foliar y biomasa medidas a través del tiempo. El rendimiento comercial obtenido en Juana Díaz, basado en un promedio de dos años, tendió a ser mayor que en Lajas por 1,594 kg/ha. En Juana Díaz se encontró una mayor eficiencia del uso de agua que en Lajas. Los estimados de $\mathrm{ET}_{\mathrm{c}}$ fueron menores en Lajas.

Palabras clave: calabaza, rendimiento, evapotranspiración, bandeja de evaporación

\section{INTRODUCTION}

In the United States up to $90 \%$ of all water resources are used for irrigation of agricultural lands (Still and Davies, 1993). However, there is much concern with the decrease of aquifers and water reservoirs, especially in heavily populated areas and large areas dedicated to agricultural production. In Puerto Rico, $40 \%$ of groundwater (374 million liters/day) is used for irrigation, whereas surface-water supplies in the north-central coast and San Juan areas are used to near capacity for non-agricultural uses (U.S. Geological Survey, 1988).

Irrigation is a practice with high energy demand; thus maximization of crop water use efficiency (WUE) is essential. Increased WUE of crops must be sought in management practices because of limitations of rainfall, diminishing aquifers, and competition with non-agricultural sectors. It is important to know the water requirement of a given crop in order to maximize WUE. One way to achieve this maximization is by using drip irrigation (Srinivas et al., 1989).

In an attempt to increase yields, most vegetable producers irrigate three to five times a week. Many times this practice results in over irrigation, which in turn causes waterlogging in poorly permeable soils, 
and favors conditions for nitrogen losses in areas with high permeability, thus contaminating groundwater and promoting cracked fruits (Anderson, 1977). Evapotranspiration of excess irrigation water may increase salt concentration at the soil surface that may result in decreased yields, reducing farmers' income. On the other hand, under irrigation may cause water stress in the plant, which during critical periods of crop development has an adverse impact on plant growth (vegetative and reproductive) and crop yield. One way to reduce water stress during critical periods is to schedule irrigation (Smajstrla et al., 1998). Although soil water availability has a strong influence on crop development and yield performance, little information is available in the Caribbean on water requirement of pumpkins.

Pumpkin has traditionally been an important crop in the Caribbean. In Puerto Rico, pumpkin is the second most important vegetable crop with a production during 2009-10 of 8,717 MT and a farm value of 4.1 million (Department of Agriculture of Puerto Rico, 2011). A large portion of the land available for farming in southwestern Puerto Rico is used for pumpkin production. This region, characterized by erratic and limited rainfall, must be supplemented by irrigation to ensure acceptable commercial yields. Good irrigation and fertigation practices are essential for the successful production of pumpkin.

The Food and Agriculture Organization (FAO) stated that the Penman-Monteith method is the standard method for estimating ET over other methods, including the Pan A evaporation method (Allen et al., 1998; Harmsen et al., 2002). The recommendation of the PenmanMonteith method occurred after the conceptualization of the research below discussed. The main goal of the project is to study the response of pumpkin to different levels of microirrigation, not to validate or question the different methods to estimate ET. The use of other method not recommended by the FAO does not invalidate the results, especially when the inputs required by the recommended method were difficult to obtain at the time of the research. Precisely, the major limitation for using this method in Puerto Rico is the lack of real-time data for the parameters needed. The Agricultural Experiment Station (AES) has developed a web-based tool to estimate the input needs by the PenmanMonteith method using averaged historical data. In the United States, and throughout the world, the use of Pan A evaporator is recognized as the standard method for measuring evaporation. Pan evaporation measurements are taken daily by qualified personnel in weather stations, and data forwarded to The Weather Bureau to keep a long-term historical weather data set. Daily evapotranspiration of a growing crop can be estimated with evaporation pans by using appropriate predetermined constants (Doorenbos and Pruitt, 1975). The Pan A evapora- 
tion method is simple and provides a measurement of the integrated effect of radiation, wind, temperature, and humidity on the evaporation from an open surface (Allen at al., 1998). In addition, the Pan A method has been widely evaluated in the Caribbean and is the method recommended by the AES. Fractions of evapotranspiration replenishment treatments were also used on banana and papaya in Puerto Rico (Goenaga and Irizarry, 1995; Goenaga et al., 2004).

Further research is needed to determine the effect of irrigation on pumpkin growth and phenology to increase crop yield, improve quality and reduce production cost in Puerto Rico. The objectives of this study were to evaluate the effect of evapotranspiration replenishment on growth and productivity of pumpkins under tropical conditions, and to determine water requirements for pumpkin under tropical conditions.

\section{MATERIALS AND METHODS}

\section{Locations description}

Pumpkin's [Cucurbita moschata (Duchesne) Poir cv. Soler] response to microirrigation studies were conducted at Lajas $\left(18^{\circ} 02^{\prime} \mathrm{N}\right.$ and $\left.67^{\circ} 04^{\circ} \mathrm{W}\right)$ and Juana Díaz $\left(18^{\circ} 01^{\prime} \mathrm{N}\right.$ and $\left.66^{\circ} 31^{\prime} \mathrm{W}\right)$ Agricultural Experiment Substations of the University of Puerto Rico. The soils at the experimental sites are classified as Fraternidad (Typic Haplusterts) and San Antón (Cumulic Haplustolls) for Lajas and Juana Díaz, respectively (Beinroth et al., 2003). Long-term data indicate a mean rainfall deficit of $10.4 \pm 5.2$ $\mathrm{cm}$ for Juana Diaz and a deficit of $5.85 \pm 5.5 \mathrm{~cm}$ for Lajas.

The soil was plowed and disked twice. Seed provided by the breeding program of AES was sown by hand on beds $1 \mathrm{~m}$ wide and $3.6 \mathrm{~m}$ apart covered with a 152 -cm-wide aluminum color plastic mulch (Beaver et al., 1995). Plant spacing within beds was $1 \mathrm{~m}$. The drip irrigation system used consisted of $5.08-\mathrm{cm}$ polyethylene submains and laterals, with drippers spaced $20 \mathrm{~cm}$ apart. Insects were controlled with applications of Methomyl $90 \mathrm{WSP}^{7}$, Bacillus thruringiensis, subspecies kurstaki and/or aizawai, alternated with Endosulfan 3EC. Applications of Chlorothalonil, Benomyl, and Triadimefon, were used to control diseases. Weeds were controlled chemically and by hand as needed. Pumpkin fertilization was according to AES recommendations (Agricultural Experiment Station, 1998).

\footnotetext{
${ }^{7}$ The company or trade names in this publication are used only to provide specific information. Mention of a company or trade name does not constitute a warranty of equipment or materials by the Agricultural Experiment Station of the University of Puerto Rico, nor is this mention a statement of preference over other equipment or materials.
} 


\section{Microirrigation scheduling}

The Pan A evaporation method was utilized to estimate reference evapotranspiration (ET $)$ and pumpkin evapotranspiration (ET), utilizing equation [1] (Smajstrla et al., 1998).

$\mathrm{ET}=(\mathrm{Epan})(\mathrm{Kp})(\mathrm{Kc})$

Where:

Epan = Pan A evaporation reading, $\mathrm{mm}$

$\mathrm{Kp}=$ Pan coefficient, unitless

$\mathrm{Kc}=$ Crop coefficient, unitless

The product of Epan and Kp provides an estimate of $\mathrm{ET}_{0}$ for the location being studied. A Ke value depends on anatomical, morphological, and physiological characteristics of the plant. The product of $\mathrm{ET}_{0}$ and $\mathrm{Kc}$ provides an estimate of actual ET for the given crop (pumpkin in this case). In the experiment we used the same approach reported by Goenaga and Irrizarry (1995), in which $\mathrm{Kp}$ and Kc values were averaged for the growing season and location. The averaged $\mathrm{Kp}$ values used were 0.63 and 0.66 (valid for January to June) for Juana Díaz and Lajas, respectively. An averaged $\mathrm{Kc}$ value of 0.78 was used for pumpkin. The $\mathrm{Kc}$ and $\mathrm{Kp}$ estimates are based on mathematical models and long-term climate for the locations and crop studied (Goyal et al., 1989).

Irrigation treatments were applied twice weekly at 72-hour intervals, after three full uniform irrigations to aid seedling establishment. Water application was based on daily cumulative ET from the previous irrigation, and controlled accurately by volumetric valves, and measured with flow meters. A $90 \%$ efficiency of the microirrigation systems was assumed (AES, 1998). Rainfall and evaporation data was taken daily from the weather station at each location.

Treatments, experimental design and data analysis

The experimental design at both locations was a randomized complete block design with split plot arrangement with four replications. The whole plot treatment corresponded to four evapotranspiration replenishment treatments (ERT). The fractions (25, 50, 75, and 100\%) were tested during 1999 and 2000 at Lajas and Juana Díaz. During 2001 , a $125 \%$ ERT was included and the $25 \%$ ERT eliminated in the study. With the use of equation [1], the estimated amount of water applied in the experimental plot for treatment 25\% ERT was too low. As a result, the distribution of irrigation water in the plot was not uniform. Based on the results obtained in the two previous years, in which no significant differences between treatments were found, we decided 
to add a $125 \%$ ERT treatment to observe the response with a greater amount of microirrigation. The subplot treatment corresponded to leaf area and dry matter-sampling dates $(3,5,7$, and $9 \mathrm{wk}$ after planting and at harvest). Treatments and planting dates are described in Table 1. Plant samples were oven-dried at $60^{\circ} \mathrm{C}$ for dry matter determination. Leaf area was measured with a leaf area meter (LI-3100). These variables were measured in two plants and pooled together to obtain an average response per subplot. Total and commercial yields were measured. Immature fruits and those weighing less than $1 \mathrm{~kg}$ at harvest were considered non-commercial. Variables evaluated were analyzed with ANOVA and regression analysis. Least Significant Difference was utilized for mean separation (SAS, 2002).

\section{RESULTS AND DISCUSSION}

\section{Plant growth}

A high variability associated with means was observed in leaf area and dry matter measurements. A test for normality and equality of variance showed that leaf area and dry matter data did not meet analysis of variance (ANOVA) assumptions. Therefore, the data was analyzed by using the natural logarithm function, thus reducing variability and improved satisfaction of ANOVA assumptions (Table 2).

The research was conducted three times from 1999 to 2001. Because of a miscalculation on plot size during the 2001 trial, preplanned treatments $(50,75,100$, and $125 \%$ ERT) resulted in 55, 82, 110, and $137 \%$ ERT for both locations. The $10 \%$ over irrigation in each treatment was assumed as negligible, and from now on treatments will be reported as initially stated.

The analysis showed that ERT did not affect pumpkin leaf area development at Lajas (Table 2). A significant interaction was found only for Juana Díaz in 2001. At Juana Díaz, early growth expressed by leaf area was greater than at Lajas during 1999 and 2000. At harvest (late stage of growth or more than 100 days after planting), the highest leaf area recorded during 1999 at Lajas was close to $30,000 \mathrm{~cm}^{2} /$ plant whereas for Juana Díaz it was $40,000 \mathrm{~cm}^{2} /$ plant (Figure 1). During 2000 leaf areas for both locations were substantially lower than those registered during 1999; leaf area development was greater at Lajas. During 2001 adverse climatic conditions affected field experiments at both locations, therefore leaf area data recorded at harvest were not analyzed. In 2001 at Juana Díaz, a significant interaction was found between ERT (whole treatment) and leaf area sampling date (sub plot treatment). At the second sampling, 40 days after plant- 
TABLE 1. Planting dates, evapotranspiration replenishment treatments (ERT) evaluated in pumpkin irrigation studies at two locations from 1999-2002.

\begin{tabular}{lccl}
\hline Location & ERT evaluated, $\%$ & Planting date & \multicolumn{1}{c}{ Sampling dates } \\
\hline Lajas & $25,50,75,100$ & 17 March 1999 & 5 April, 19 April, 4 May, 18 May, 29 June \\
& $25,50,75,100$ & 1 March 2000 & 21 March, 4 April, 18 April, 2 May, 27 June \\
Juana Díaz & $50,75,100,125$ & 23 February 2001 & 20 March, 3 April, 17 April \\
& $25,50,75,100$ & 19 February 1999 & 16 March, 30 March, 13 April, 27 April, 1 June \\
& $25,50,75,100$ & 20 March 2000 & 11 April, 25 April, 9 May, 23 May, 13 July \\
& $50,75,100,125$ & 2 March 2001 & 27 March, 10 April, 24 April \\
\hline
\end{tabular}

TABLE 2. Analysis of variance of pumpkin 'Soler' natural log of leaf area $\left(\mathrm{cm}^{2} /\right.$ plant $)$ and dry matter ( $\mathrm{g} /$ plant) affected by four evapotranspiration replenishment treatments (ERT) at Lajas and Juana Diaz during a three-year period.

\begin{tabular}{|c|c|c|c|c|c|c|c|c|c|c|c|c|}
\hline \multirow[b]{4}{*}{ Sources of Variation } & \multicolumn{12}{|c|}{$\operatorname{Pr}>\mathrm{F}$} \\
\hline & \multicolumn{6}{|c|}{ Leaf Area } & \multicolumn{6}{|c|}{ Dry Matter } \\
\hline & \multicolumn{3}{|c|}{ Lajas } & \multicolumn{3}{|c|}{ Juana Díaz } & \multicolumn{3}{|c|}{ Lajas } & \multicolumn{3}{|c|}{ Juana Díaz } \\
\hline & 1999 & 2000 & 2001 & 1999 & 2000 & 2001 & 1999 & 2000 & 2001 & 1999 & 2000 & 2001 \\
\hline ERT & NS & NS & $\mathrm{NS}$ & NS & NS & NS & NS & NS & NS & 0.0586 & NS & NS \\
\hline Sampling Date (SD) & 0.0001 & 0.0001 & 0.0001 & 0.0001 & 0.0001 & 0.0001 & 0.0001 & 0.0001 & 0.0001 & 0.0001 & 0.0001 & 0.0001 \\
\hline ERT*SD & NS & NS & NS & NS & NS & 0.0071 & 0.0567 & 0.0811 & NS & NS & NS & 0.0853 \\
\hline $\mathrm{CV}$ & 12.2 & 3.6 & 3.78 & 6.0 & 6.29 & 3.87 & 21 & 5.6 & 6.93 & 10.9 & 6.5 & 5.57 \\
\hline
\end{tabular}




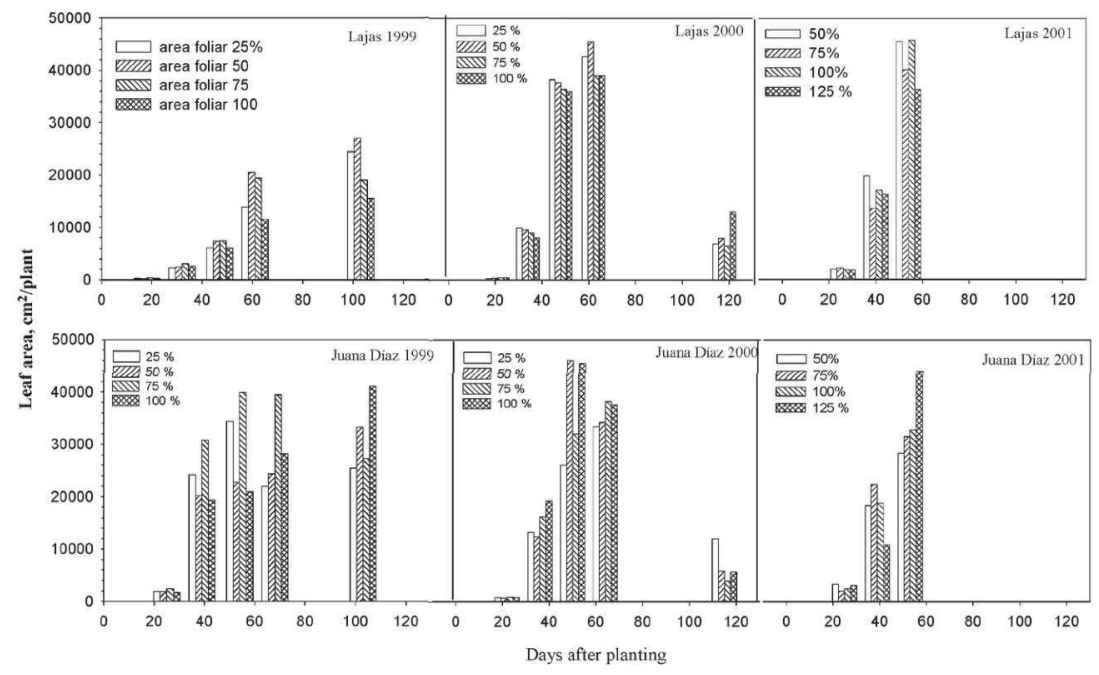

FIGURE 1. Leaf area of pumpkin (cv. Soler) as affected by four evapotranspiration replenishment treatments at Lajas and Juana Díaz.

ing (dap), plants submitted to $100 \%$ ERT $\left(22,622 \mathrm{~cm}^{2} /\right.$ plant $)$ resulted in a significantly larger leaf area than those with $125 \%\left(12,971 \mathrm{~cm}^{2} /\right.$ plant). In the third sampling (57 dap), treatment $125 \%$ ERT $(52,713$ $\mathrm{cm}^{2} /$ plant) produced higher leaf area in comparison with that of $100 \%$ ERT $\left(39,381 \mathrm{~cm}^{2} /\right.$ plant $)$. Results indicate that high microirrigation levels (ERT) applied at early stages of plant development ( $<40$ dap) reduce pumpkin growth.

In 1999, the observed dry matter accumulation at Juana Díaz was affected significantly by ERT (Table 2; Figure 2). Dry matter production was significantly reduced with the application of $100 \%$ ERT. No other significant differences were observed in dry matter accumulation at either location during 2000 and 2001.

\section{Pumpkin yield}

Some management practices used at each location, such as planting and sampling dates, and pesticides (rate and number of applications) were different, thus the data obtained from each trial was analyzed separately. Overall yield data varied considerably between trials and treatments. Yield data of 1999 was not analyzed because severe weather conditions damaged the experiment at both locations. The experiments were repeated during 2002 , but only yield data was recorded (Table 3). At both locations it was possible to record only two years of yield data. During the years when the experiment was 


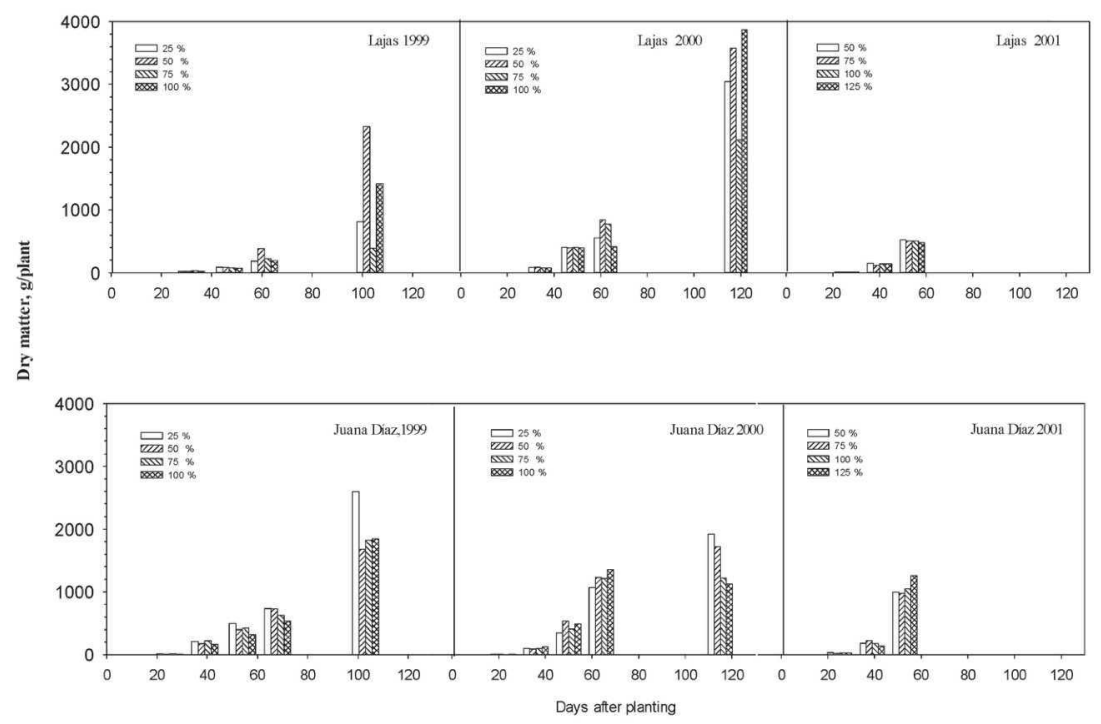

FIGURE 2. Dry matter pumpkin (cv. Soler) as affected by four evapotranspiration replenishment treatments at Lajas ad Juana Díaz.

conducted, adverse weather conditions affected the trials; therefore, we were unable to obtain a complete data set of yield, leaf area or biomass for the four-year period. The research team understands that it is worthwhile to present the data, although it is not a complete set, because farmers of the region face the same problems in pumpkin cultivation.

Commercial two-year average yield was $22,516 \mathrm{~kg} / \mathrm{ha}$ for Lajas and $24,110 \mathrm{~kg} / \mathrm{ha}$ for Juana Díaz. There were no significant differences in commercial yield regardless of ERT or location (Table 3). Total and commercial yield data by location, microirrigation treatment and years are included in Table 3. Significant differences were found only for total yield in 2001 for Juana Díaz, with LSD value of $27,709 \mathrm{~kg} / \mathrm{ha}$ (Table 3 ). The higher total yield was recorded with $75 \%$ ERT. No logical explanation or trend can be inferred for this result.

Beaver et al. (2006) reported pumpkin 'Soler' yields of 24,728 and $12,838 \mathrm{~kg} / \mathrm{ha}$ for June and August, 2004, respectively, at Lajas. Yields reported in this study varied from $33,205 \mathrm{~kg} / \mathrm{ha}$ for 2000 to $11,828 \mathrm{~kg}$ / ha for 2002, whereas Beaver et al. (2006) reported average yields of 36,470 and $34,410 \mathrm{~kg} / \mathrm{ha}$ for Juana Díaz. 'Soler' is the standard pumpkin cultivar grown in Puerto Rico (Beaver, 2005). 
TABLE 3. Pumpkin total and commercial yield $(\mathrm{kg} / \mathrm{ha}$ ) as affected by four evapotranspiration replenishment treatments (ERT\%) at Lajas and Juana Díaz during a three-year period.

\begin{tabular}{|c|c|c|c|c|c|c|c|c|c|c|c|c|}
\hline \multirow[b]{3}{*}{ ERT } & \multicolumn{6}{|c|}{ Lajas } & \multicolumn{6}{|c|}{ Juana Díaz } \\
\hline & \multicolumn{3}{|c|}{ Total } & \multicolumn{3}{|c|}{ Commercial } & \multicolumn{3}{|c|}{ Total } & \multicolumn{3}{|c|}{ Commercial } \\
\hline & 2000 & 2001 & 2002 & 2000 & 2001 & 2002 & 2000 & 2001 & 2002 & 2000 & 2001 & 2002 \\
\hline $\begin{array}{l}25 \\
50\end{array}$ & $\begin{array}{l}40,594 \\
33,252\end{array}$ & - & $\begin{array}{l}36,752 \\
38,455\end{array}$ & $\begin{array}{l}35,985 \\
29,672\end{array}$ & - & $\begin{array}{l}13,983 \\
11,991\end{array}$ & $\begin{array}{l}12,979 \\
12,241\end{array}$ & 38,316 & - & $\begin{array}{r}9,323 \\
10,110\end{array}$ & $32 \overline{2,986}$ & - \\
\hline 75 & 39,112 & - & 29,588 & 32,925 & - & 9,120 & 12,289 & 32,201 & - & 9,335 & 29,421 & - \\
\hline 100 & 37,805 & - & 31,535 & 34,237 & - & 12,217 & 15,503 & 64,567 & - & 12,907 & 53,893 & - \\
\hline 125 & - & - & - & - & - & & - & 46,732 & - & - & 34,907 & - \\
\hline average & 37,691 & & 34,083 & 33,205 & & 11,828 & 13,253 & 45,454 & & 10,419 & 37,802 & \\
\hline $\operatorname{LSD}(0.05)$ & NS & - & NS & NS & - & NS & NS & 27,709 & - & NS & NS & \\
\hline
\end{tabular}

- data not available. 


\section{Irrigation}

Generally, rainfall recorded in Lajas was higher than that in Juana Díaz, but evaporation was lower. Higher evaporation readings registered in Juana Díaz resulted in higher irrigation requirements than at Lajas (Table 4). The average pumpkin evapotranspiration estimated for Juana Díaz with the Pan A method (100\% ERT) doubled $(5.1 \mathrm{~mm} /$

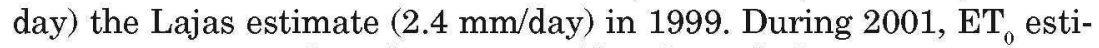
mate at Lajas was less than $3.0 \mathrm{~mm} /$ day through the growing season. On the other hand, values up to $6 \mathrm{~mm} /$ day were estimated for Juana Díaz (Figure 3). Goyal (1989) calculated an average $\mathrm{ET}_{0}$ of $3.36 \mathrm{~mm} /$ day (February to April) for Lajas, and $4.01 \mathrm{~mm} /$ day for Juana Díaz. Pan derived $\mathrm{ET}_{0}$ values were overestimated for Juana Díaz and underestimated for Lajas when compared with values calculated by Goyal et al. (1989). The fractions of ERT results reported herein are supported by crop response data, contrasting with the values published by Goyal et al. (1989) which were based on weather data sets of 16 and 31 years for Juana Díaz and Lajas, respectively, and calculated by using the Blaney-Criddle method.

To facilitate discussion of actual microirrigation applied to the crop, only irrigation applied at $100 \% \mathrm{ERT}$ is presented. The $\mathrm{ET}_{0}$ values were estimated for the corresponding date, then the fraction of ERT was calculated utilizing equation [1] and the corresponding water amount for

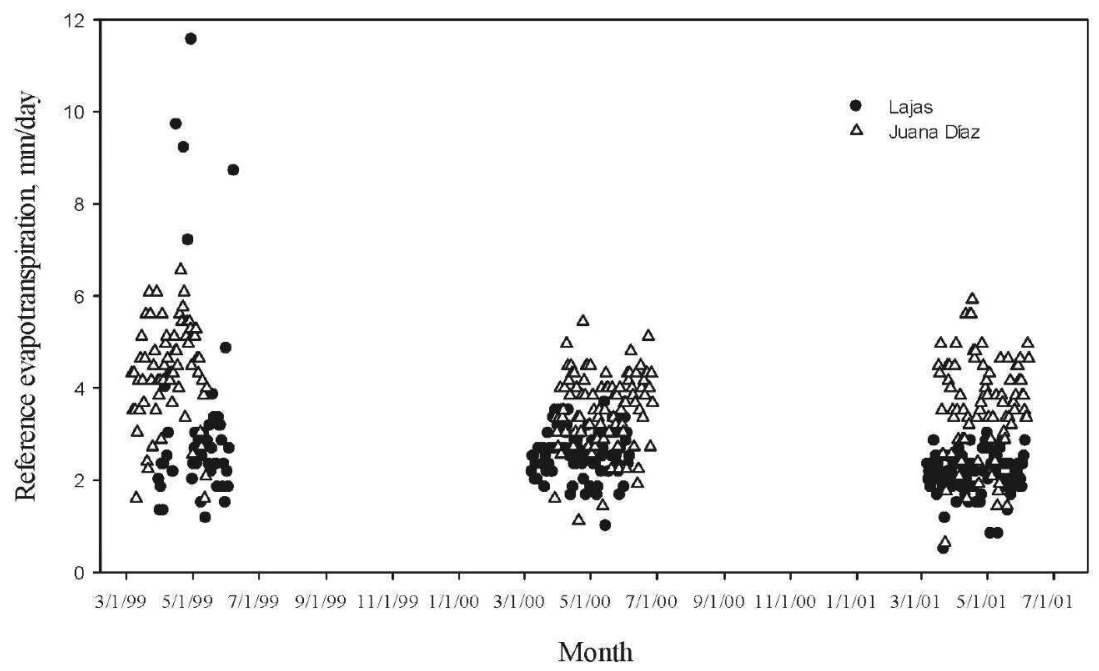

FIGURE 3. Reference evapotranspiration estimated by using Pan A evaporation method at Lajas and Juana Díaz during a three years period. 
each microirrigation treatment was delivered to plants. The microirrigation applied or water applied is finally presented in terms of water depth (Table 4).

In April and May, pumpkin plants showed a high irrigation requirement for Juana Díaz and Lajas, respectively. Total microirrigation applied at Lajas varied from 28 to $31 \mathrm{~mm}$, whereas at Juana Díaz it varied from 47 to $56 \mathrm{~mm}$. Higher microirrigation requirement shown at Juana Díaz is the result of higher pan evaporation readings.

Total water applied to the system (rainfall + irrigation) averaged from 4.38 to $19.00 \mathrm{~mm} /$ week for Lajas whereas at Juana Díaz it varied from 12.25 to $24.6 \mathrm{~mm} /$ week. It is important to point out that in 1999 the average amount of water applied in Lajas was low $(4.38 \mathrm{~mm} /$ week $)$ compared with the AES recommendation of $19 \mathrm{~mm} /$ week for pumpkin growing with plastic mulch, assuming a $90 \%$ system efficiency and $60 \%$ of the land under microirrigation. Generally, the average water requirement at 100\% ERT is 6 and $2 \mathrm{~mm}$ /week less than the recommendation for Lajas and Juana Díaz, respectively.

A study conducted in Europe during a three-year period with three winter squash (Cucurbita maxima) cultivars showed an average drip irrigation application of $147 \mathrm{~mm}$ (about $37 \mathrm{~mm} / \mathrm{month}$ ), assuming a similar growing season as that of our tropical pumpkin (Rolbiecki,

TABLE 4. Monthly rainfall and irrigation amount $(\mathrm{mm})$ applied to pumpkin ('Soler') at $100 \%$ evapotranspiration replenishment treatment (ERT) at Lajas and Juana Diaz during a three-year period.

\begin{tabular}{|c|c|c|c|c|c|c|}
\hline \multirow[b]{2}{*}{ Month } & \multicolumn{3}{|c|}{ Lajas } & \multicolumn{3}{|c|}{ Juana Díaz } \\
\hline & Rainfall & Irrigation & Total & Rainfall & Irrigation & Total \\
\hline March 1999 & - & - & & 11.9 & 21 & 32.9 \\
\hline April & 13.2 & 10 & 23.2 & 19.0 & 29 & 48.0 \\
\hline May & 7.6 & 15 & 22.6 & 60.7 & 6 & 66.7 \\
\hline June (first week) & 3.8 & 3 & 6.8 & - & - & - \\
\hline Total & 24.6 & 28 & 52.6 & 91.6 & 56 & 147.6 \\
\hline March 2000 & 31.8 & 9 & 39.8 & - & - & - \\
\hline April & 65.2 & 9 & 74.2 & 31.7 & 20 & 51.7 \\
\hline May & 114.0 & 8 & 122.0 & 206.9 & 13 & 219.9 \\
\hline June & 0 & 4 & 4.0 & 6.3 & 19 & 25.3 \\
\hline Total & 211.0 & 30 & 241.0 & 244.9 & 52 & 296.9 \\
\hline March 2001 & 30.2 & 8 & 38.2 & - & - & - \\
\hline April & 92.7 & 7 & 99.7 & 47.2 & 8 & 55.2 \\
\hline May & 38.4 & 12 & 50.4 & 134.6 & 20 & 154.6 \\
\hline June & 0 & 4 & 4.0 & 0 & 19 & 9.0 \\
\hline Total & 161.3 & 31 & 192.3 & 181.8 & 47 & 163.6 \\
\hline
\end{tabular}

- Experiment not yet established 
2004). In the same study the authors reported an average WUE of 153 $\mathrm{kg} / \mathrm{ha} / \mathrm{mm}$ of drip irrigation.

The approach of using an average $\mathrm{Kc}$ value through the pumpkin growing season ( $\mathrm{Kc}=0.78$ ) overestimates microirrigation requirements at early stage of development and underestimates it at fruit rapid growth rate. The predominant soils (Mollisols and Vertisols) in which the studies were conducted have a high water-holding capacity; therefore, any excess of water is stored in the soil profile. Stored water is available later on when the plant has a higher water requirement. In case of high rainfall, the chances of losing water away from the root zone increase, mostly at early stages of development.

There was no significant effect of irrigation treatments on leaf area and dry matter in most of the years during which time this study was conducted. Therefore, a $\mathrm{Kp}$ value higher than the one we used (0.66) will result in higher microirrigation requirements, increasing the chances of water losses with no consequent pumpkin yield or growth increase.

Harmsen et al. (2004) reported a reduction in evaporation over a period of ten years in the Lajas Substation. Those authors recommended checking evaporation values using other nearby weather stations. If evaporation reduction is confirmed, they suggested using an adjusted $\mathrm{Kp}$ value greater than 1.0 to estimate $\mathrm{ET}_{0}$. The results of the three-year study here reported did not show a significant effect of irrigation treatments on growth and production of pumpkin. If a greater $\mathrm{Kp}$ value had been used in this study ( $>0.66$ ), as recommended by Harmsen et al. (2004), calculations would have resulted in a higher estimated water requirement, increasing the likelihood of water loss with no increase in crop production.

\section{CONCLUSION}

The results obtained through this research suggest that a microirrigation application less than $100 \%$ ERT is sufficient to maintain adequate pumpkin growth and yield for the southwestern region of Puerto Rico. The AES recommendation of $19 \mathrm{~mm} /$ week should be reduced. In none of the months during the pumpkin growing seasons of three years, was the level of irrigation applied greater than $29 \mathrm{~mm} / \mathrm{month}$ (7.25 mm/week) in Juana Díaz or $12 \mathrm{~mm} / \mathrm{month}$ ( $3 \mathrm{~mm} /$ week) in Lajas. Pumpkin yields tended to be greater at Juana Díaz than at Lajas, results which were similar to those reported by Beaver et al. (2006). The low evaporation values recorded in Lajas that led to estimates of crop water requirements (ETc) lower than in Juana Díaz, did not reduce yields by an underestimation of the amount of microirrigation applied. 
It seems that other factor (s) such as soil physical properties or other climatic variables caused lower 'Soler' pumpkin yields at Lajas.

An approximate WUE value can be determined dividing the total yield by total water applied to the system (consisting of the sum of rainfall and microirrigation applied). Estimated WUE values for Juana Díaz ( 89 to $153 \mathrm{~kg} / \mathrm{ha} / \mathrm{mm}$ ) indicate that microirrigation tends to be more efficient than at Lajas (177 to $716 \mathrm{~kg} / \mathrm{ha} / \mathrm{mm}$ ).

We hypothesized that the pan evaporation reduction observed at Lajas was due to the nearness of the weather station to a replicated tree biomass experiment. Based on the results obtained in this and other studies we recommend that farmers use some method to schedule microirrigation in pumpkins. The recommendation of a fixed application of water of $19 \mathrm{~mm} /$ week is excessive because of the great variability observed in rainfall patterns in the regions where it is produced and the lack of consistent response to microirrigation levels.

\section{LITERATURE CITED}

Agricultural Experiment Station, 1998. Conjunto tecnológico para la producción de calabaza. Publicación 155. College of Agricultural Sciences, University of Puerto RicoMayagüez.

Allen, R. G., L. S. Pereira, D. Raes and M. Smith, 1998. Crop evapotranspiration guidelines for computing crop water requirements. FAO. Irrigation and Drainage Paper 56, Food and Agriculture Organization of the United Nations, Rome.

Anderson, H., 1977. Ground water in the Lajas Valley. Water Resources Division. U.S. Geological Survey. US Department of the Interior.

Beaver, L. W., 2005. Release of 'Soler' tropical pumpkin. J. Agric. Univ. P.R. 89(3-4): 263-266.

Beaver, L. W., O. Román-Hernández and L. E. Flores-López. 2006. Performance of new tropical pumpkin genotypes under varying cultural practices. J. Agric. Univ. P.R. 90(3-4): 193-206.

Beinroth, F. H., R. J. Engel, J. L. Lugo, C. Santiago, S. Ríos and G. R. Brannon, 2003. Updated taxonomic classification of the soils of Puerto Rico, 2002. Bulletin 303. Agricultural Experiment Station, College of Agricultural Science, University of Puerto Rico, Mayagüez Campus.

Department of Agriculture of Puerto Rico, 2011. Ingreso bruto de la agricultura de Puerto Rico-cifras revisadas 2008-2009 y preliminares 2009-2010. Oficina Estadísticas Agrícolas. Gobierno de Puerto Rico, San Juan.

Doorenbos, J. and W. O. Pruit, 1975. Crop Water requirements. Irrigation and Drainage paper No. 24 FAO, Rome.

Goenaga, R. and H. Irizarry, 1995. Yield performance of banana irrigated with fraction of Class A evaporation in a semiarid environment. Agron. J. 87: 172-176.

Goenaga, R., E. Rivera and C. Almodóvar, 2004. Yield of papaya irrigated with fraction of Class A evaporation in a semiarid environment. Agron. J. 88(1-2): 1-10.

Goyal, M. R. (Ed.), 1989. Irrigation research and extension progress in Puerto Rico. Agricultural Experiment Station. University of Puerto Rico.

Harmsen, E. W., M. R. Goyal and S. Torres-Justiniano, 2002. Estimating evapotranspiration in Puerto Rico. J. Agric. Univ. P.R. 86(1-2): 35-54. 
Harmsen, E. W., A. González-Pérez and A. Winter, 2004. Re-evaluation of Pan evaporation coefficients at seven locations in Puerto Rico. J. Agric. Univ. P.R. 88(3-4): 109-122.

Rolbiecki, R., 2004. Effect of microirrigation of chosen cultivars of winter squash (Cucurbita maxima Duch. F.) cultivated on the very light soil. Hortorum Cultus 3(1): 37-41.

SAS Institute, 2002. SAS/STAT: Guide for personal computers. Version 8. Cary, NC.

Smajstrla, A. G., F. S. Zazueta, G. A. Clark and D. J. Pitts, 1998. Irrigation scheduling with evaporation pans. Bulletin 254. Cooperative Extension Service. Institute of Food and Agricultural Sciences. Univ. of Fla.

Srinivas, K., D., M. Hedge, and G. V. Havanagi, 1989. Plant water relation, canopy temperature, yield and water-use efficiency of watermelon Citrulus lanatus (Thumb.) Matsum et Nakai under drip and furrow irrigation. J. Hort. Sci. 64(1): 115-124.

Still, D. W. and F. T. Davies Jr., 1993. Water use, water-use efficiency and growth analysis of selected woody ornamentals species under non-limiting water regimes. Scientia Horticulturae 53: 213-223.

U.S. Geological Survey, 1988. Ground-water studies in Puerto Rico. US Department of the Interior. Report 88-162. 
